\title{
Factors affecting production of Chinese Chestnut in Xinxian County, Henan Province, China
}

\author{
by Wang Gaoping ${ }^{1}$, Yan Qing ${ }^{1}$, Zhang $\mathrm{Kai}^{1}$ and William M. Ciesla ${ }^{2,3}$
}

Chestnuts, Castanea mollissima Blume, are an important non-wood forest product in XinXian County, Henan Province, China. As part of an effort to improve capacity to reduce crop losses caused by insects and other damaging factors, a monitoring system was established in four orchards representing various ages, growing conditions and management practices. Monitoring consisted of periodic observations of the condition of chestnuts through a portion of the 2000 season on sample trees. Resulting data were summarized into life tables.

The monitoring indicated that less than $50 \%$ of the chestnut burrs present on the trees in early July survived to harvest. Missing burrs were the highest cause of chestnut loss in three of the four orchards sampled. This may in part be the result of chestnut burrs aborting because of insect attack, spontaneous abortion or early maturation of chestnuts. Losses that could be directly attributed to insects ranged between 12.75 and $28.58 \%$, caused mainly by several species of caterpillars that bore into chestnuts. Occurrence of "empty burrs" was roughly equal to insect damage levels in two orchards that did not receive a supplemental boron fertilizer treatment at the time of flowering.

Based on monitoring data obtained during the 2000 growing season, opportunities to increase chestnut production in XinXian County include application of boron to increase nut set and development of an Integrated Pest Management (IPM) system with emphasis on management of lepidopterous borers.

Key words: Chinese chestnut, Castanea mollissima, integrated pest management, life tables, insect pests, non-wood forest products

Les marrons, Castenea mollissima Blume, constituent une importante ressource forestière non ligneuse pour le comté de Xinxian de la province d'Henan, en Chine. En tant qu'élément des efforts faits pour améliorer la capacité de réduction des pertes de fruits provoquées par des insectes et d'autres facteurs de perte, un système de surveillance a été mis en place dans quatre vergers représentant différents âges, conditions de croissance et pratiques d'aménagement. La surveillance a pris la forme d'observations périodiques de l'état des marrons au cours d'une portion de 2000 sur des arbres échantillons. Les données recueillies ont été résumées sous forme de tableaux.

La surveillance a indiqué que moins de $50 \%$ des brous de marrons présents sur les arbres au début de juillet ont survécu jusqu'à la récolte. Les brous de marrons manquant ont été la plus importante cause de perte de fruits dans trois des quatre vergers échantillonnés. Cette situation peut être en partie le résultat de l'avortement des marrons à la suite d'une attaque d'insecte, d'un avortement spontané ou d'une maturation précoce des marrons. Les pertes qui pourraient être attribuées directement aux insectes se situaient entre 12,75 et $28,58 \%$, et principalement causées par différentes espèces de chenilles qui percent les marrons. La présence de «brous vides» était à peu près égale aux niveaux de dégâts par les insectes dans les deux vergers qui n'avaient pas reçu un supplément de fertilisant à base de boron au moment de la fertilisation.

En fonction des données de surveillance obtenues au cours de la saison de croissance 2000, les possibilités d'accroître la production de marrons dans le comté de XinXian se rapportent à l'application de boron pour accroître la formation et le développement d'un système d'aménagement intégré des ravageurs mettant l'accent sur le contrôle des lépidoptères perceurs.

Mots clés: marrons chinois, Castenea mollissima, aménagement intégré des ravageurs, tableaux synoptiques, insectes ravageurs, produits forestiers non ligneux

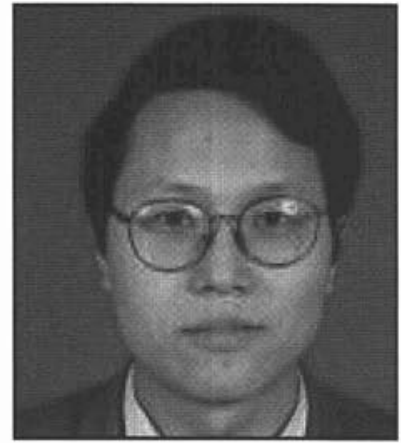

Wang Gaoping

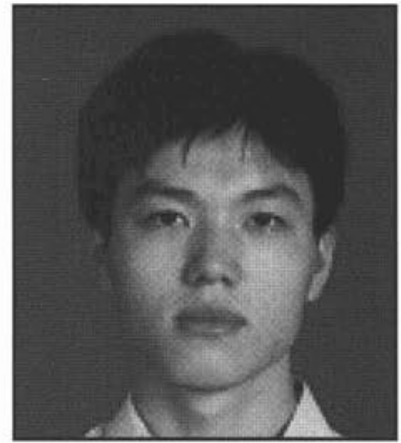

Yan Qing

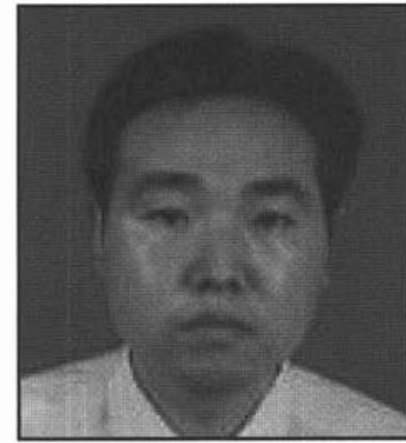

Zhang Kai

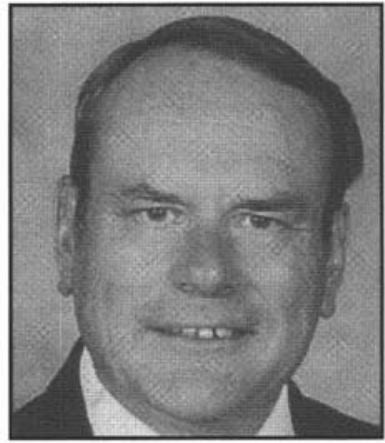

William M. Ciesla

'Department of Plant Protection, Henan Agricultural University, Zhengzhou 450002, China.

${ }^{2}$ Forest Health Management International, 2248 Shawnee Court, Fort Collins, CO, 80525, USA.

${ }^{3}$ Funding for this project was provided through the Technical Cooperation Programme of the Food and Agriculture Organization of the United Nations (FAO) - TCP/CPR/8925 ( $t$ ) - Integrated Pest Management and Storage of Chestnuts in XinXian County.

\section{Introduction}

XinXian County, located in the Dabieshan Mountains of southern Henan Province, is one of China's leading producers of Chinese chestnuts, Castanea mollissima. Some 13000 ha are dedicated to chestnut production, yielding an annual crop of about 10000 tonnes. These orchards are an important source 
of income in one of China's poorest counties, with an annual per capita income of Yuan 765 (about \$US 93).

In XinXian County, chestnut orchards are usually grown on steep mountain slopes although some are established on terraced slopes in agroforestry systems. The orchards are owned privately or by townships and managed communally. Trees begin to bear nuts three years after grafting and continue to produce profitable quantities of nuts for about 40 years.

Insects and diseases, on living trees and harvested chestnuts, are important factors affecting chestnut production. Current estimates indicate that roughly $20-30 \%$ of the crop is destroyed annually. In localized areas, damage may be as high as 50 percent. This equates to an annual loss of Yuan 42 million (ca. \$US 4.9 million).

In 2000, in response to a request from the Agriculture Foreign Capital Project of XinXian County, the Food and Agriculture Organization of the United Nations (FAO) provided funding and technical support through its Technical Cooperation Programme (TCP). The objective of this ongoing TCP is to provide advice and assistance in developing an Integrated Pest Management System (IPM) for chestnut orchards and in handling and storage of chestnuts, with the view of achieving increased economic, social and ecological benefits of chestnut growing and increased income for rural communities dependent on chestnut production. One of the elements of this Project is the development of a monitoring system, designed to identify key pests and to determine level and stages of loss. This paper discusses the development, implementation and first year results of the monitoring system and is the result of consultancies within the framework of the TCP.

\section{Methods \\ Orchards}

Four orchards representing various ages, growing conditions and pest management practices were selected for monitoring.

Two were located in adjacent orchards near Tianpu Township on moderately steep terrain. One orchard (about 27 ha) is owned by the Forest Extension Station of the XinXian County Forest Industry Department and the other (about $133 \mathrm{ha}$ ) is managed as a communal orchard by the Tianpu Township. Most of the trees in both orchards were six years old and averaged about two meters in height. Ground vegetative cover was moderate to heavy and contained a scattering of "wild" chestnut saplings also producing heavy chestnut crops. These orchards have been managed with different intensities. The orchard managed by the Forest Extension Station received six sprays per year, including an early spring application of boron fertilizer to stimulate nut set. In addition, branches infested by the chestnut gall wasp, Dryocosmus kuriphilus Yasumatsu (Hymenoptera: Cynipidae), had been removed and burned. The orchard managed by the Tianpu Township received two insecticide sprays per year and the trees had not been pruned to remove gall wasp infestations. Application of sprays was by hand operated, backpack pressure sprayers widely used in China for both field and tree crops (Fig. 1).

The Wuchenhe orchard, located in northern XinXian County, on gentle rolling terrain, encompassed about 67 ha. Many of the chestnut trees were planted on terraced slopes interspersed with annual crops (squash, sesame, beans and ground nuts) in an agroforestry system and were 11 to 12 years old. No insecticide treatments were carried out during 2000 .

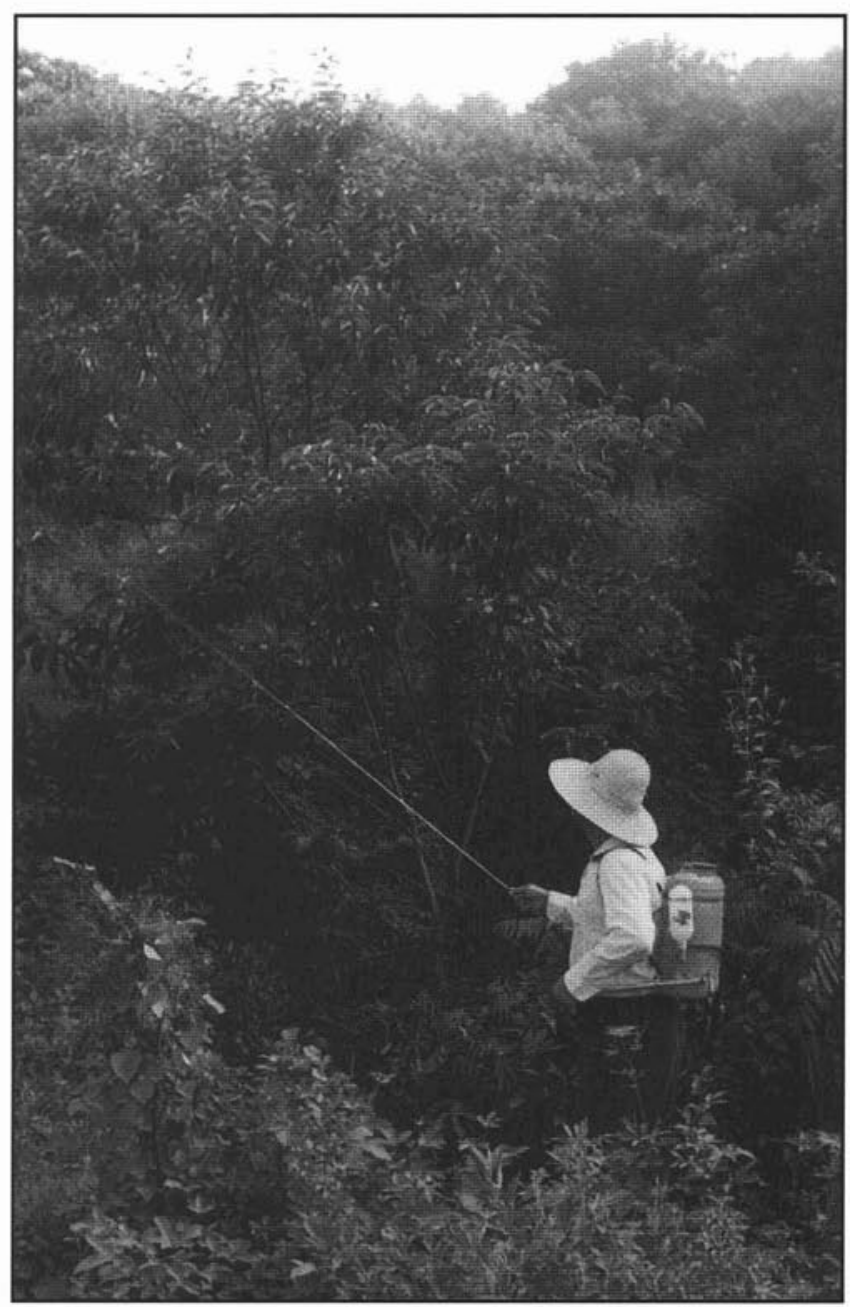

Fig. 1. Application of insecticides in a chestnut orchard in XinXian County, Henan Province, China using a hand operated, backpack pressure sprayer.

The Xinji orchard, located adjacent to a large reservoir on steep terrain about $7 \mathrm{~km}$ southeast of XinXian City, is part of the tea plantation established and owned as a commune by the Xinji Township. The largest part of the orchard was established in 1985 and trees averaged about 10 meters in height. Ground vegetative cover was heavy. In 2000, this orchard was sprayed one time with boron fertilizer to increase nut set and once for insect control.

\section{Sampling Procedure}

A total of 30 sample trees were selected randomly in each orchard and marked with brightly coloured cloth ribbon. In the two younger orchards at Tianpu, all of the chestnut burrs ${ }^{4}$ were examined on each sample tree and their condition recorded. In the Wuchenhe and Xinji orchards, four dominant branch samples, one in each cardinal direction, were selected as subsamples, marked with coloured cloth and all of the burrs on these branches were examined and classified according to condition.

${ }^{4}$ Burr is the popular designation for the fruit of trees and shrubs of the genus Castanea. Burrs have a tough, spiny coat and contain either one (chinkapins) or two to three nuts (chestnuts). 
Sample trees were examined three times during the growing season: early July, mid August and early September, coinciding with the chestnut harvest. During the July and August sample periods, damaged burrs were recorded, and, to the extent possible, classified as to causal factor, but were not removed from the trees. In early September, coinciding with harvest, all of the chestnuts were removed from the sample trees, temporarily stored in nylon mesh bags and then opened. Counts of the number of chestnuts/burr were made and the condition of each chestnut recorded.

Subsamples of damaged and aborted burrs were collected in two orchards in late August to obtain data on the identity of damaging agents and possible causes of chestnut burr abortion.
Data on the number and proportion of chestnut burrs and chestnuts by damage factor were summarized for each of the four orchards into life tables (Graham 1963).

\section{Results}

Some sample trees were lost during the growing season because of missing markers and early harvesting of chestnuts. As a result, the life tables and estimates of crop loss were based on 30 trees in the Tianpu Forest Extension Station orchard, 25 trees for Tianpu Township orchard and 19 trees each for the Wuchenhe and Xinji Orchards.

Life tables for each orchard sampled are summarized in Tables $1-4$ and level of loss by key damage factors is summarized in Fig. 2. The proportion of chestnuts on the sample trees in early

\begin{tabular}{|c|c|c|c|c|c|c|}
\hline Sample Interval & $\begin{array}{l}\text { Number alive } \\
\text { (burrs) }\end{array}$ & $\begin{array}{l}\text { Number alive } \\
\text { (chestnuts) }\end{array}$ & Factor & $\begin{array}{c}\text { Number affected } \\
\text { (burrs) }\end{array}$ & $\begin{array}{l}\text { Number affected } \\
\text { (chestnuts) }\end{array}$ & Percent Affected \\
\hline \multirow[t]{4}{*}{ Up to July 01} & 1025 & 2730.60 & Mecorhis cumulatus & 14 & 37.30 & 1.37 \\
\hline & & & Boring caterpillars & 0 & 0.00 & 0.00 \\
\hline & & & Other & 3 & 7.99 & 0.29 \\
\hline & & & Total & 17 & 45.29 & 1.66 \\
\hline \multirow{4}{*}{ July $02-$ Aug 13} & 1008 & 2685.31 & Missing & 134 & 356.98 & 13.07 \\
\hline & & & Boring caterpillars & 134 & 356.98 & 13.07 \\
\hline & & & Other & 0 & 0.00 & 0.00 \\
\hline & & & Total & 268 & 713.95 & 26.15 \\
\hline \multirow[t]{10}{*}{ Aug 14 Sept 06} & 740 & 1971.36 & Missing & 97 & 258.41 & 9.46 \\
\hline & & & Empty burrs & 51 & 135.86 & 4.98 \\
\hline & & & Dichocrocis punctiferalis & & 57.00 & 2.09 \\
\hline & & & Ch. ruficirra & & 47.00 & 1.72 \\
\hline & & & Cydia splendana & & 1.00 & 0.04 \\
\hline & & & Curculio spp. & & 5.00 & 0.18 \\
\hline & & & N. castanes & & 0.00 & 0.00 \\
\hline & & & Diseases & & 206.00 & 7.54 \\
\hline & & & Other & & 27.00 & 0.99 \\
\hline & & & Total & & 737.27 & 27.00 \\
\hline Yield & & 1234 & & & & 45.19 \\
\hline
\end{tabular}

* Based on a sample of 30 trees and 2.664 chestnuts per burr.

\begin{tabular}{|c|c|c|c|c|c|c|}
\hline Sample Interval & $\begin{array}{c}\text { Number alive } \\
\text { (burrs) }\end{array}$ & $\begin{array}{l}\text { Number alive } \\
\text { (chestnuts) }\end{array}$ & Factor & $\begin{array}{l}\text { Number affected } \\
\text { (burrs) }\end{array}$ & $\begin{array}{c}\text { Number affected } \\
\text { (chestnuts) }\end{array}$ & Percent Affected \\
\hline \multirow[t]{4}{*}{ Up to July 06} & 535 & 1465.37 & Mecorhis cumulatus & 11 & 30.13 & 2.06 \\
\hline & & & Boring caterpillars & 0 & 0.00 & 0.00 \\
\hline & & & Other & 3 & 8.22 & 0.56 \\
\hline & & & Total & 14 & 38.35 & 2.62 \\
\hline \multirow[t]{4}{*}{ July $07-$ Aug 13} & 521 & 1427.02 & Missing & 95 & 260.21 & 17.76 \\
\hline & & & Boring caterpillars & 43 & 117.78 & 8.04 \\
\hline & & & Other & 0 & 0.00 & 0.00 \\
\hline & & & Total & 138 & 377.98 & 25.79 \\
\hline \multirow[t]{10}{*}{ Aug $14-$ Sep 05} & 383 & 1049.04 & Missing & 79 & 216.38 & 14.77 \\
\hline & & & Empty burrs & 86 & 235.55 & 16.07 \\
\hline & & & Dichocrocis punctiferalis & & 4.00 & 0.27 \\
\hline & & & Ch. ruficirra & & 17.00 & 1.16 \\
\hline & & & Cydia splendana & & 18.00 & 1.23 \\
\hline & & & Curculio spp.** & & - & - \\
\hline & & & $N$. castanes & & 0.00 & 0.00 \\
\hline & & & Diseases & & 38.00 & 2.59 \\
\hline & & & Other & & 41.00 & 2.80 \\
\hline & & & Total & & 569.94 & 38.39 \\
\hline Yield & & 479 & & & & 32.69 \\
\hline
\end{tabular}

* Based on a sample of 25 trees and 2.739 chestnuts per burr.

*** No data obtained. 


\begin{tabular}{|c|c|c|c|c|c|c|}
\hline Sample Interval & $\begin{array}{c}\text { Number alive } \\
\text { (burrs) }\end{array}$ & $\begin{array}{c}\text { Number alive } \\
\text { (chestnuts) }\end{array}$ & Factor & $\begin{array}{l}\text { Number affected } \\
\text { (burrs) }\end{array}$ & $\begin{array}{l}\text { Number affected } \\
\text { (chestnuts) }\end{array}$ & Percent Affected \\
\hline \multirow[t]{4}{*}{ Up to July 03} & 452 & 1038.24 & Mecorhis cumulatus & 1 & 2.30 & 0.22 \\
\hline & & & Boring caterpillars & 15 & 34.46 & 3.32 \\
\hline & & & Other & 8 & 18.38 & 1.77 \\
\hline & & & Total & 24 & 55.13 & 5.31 \\
\hline \multirow[t]{4}{*}{ July 04-Aug 11} & 428 & 983.12 & Missing & 15 & 34.46 & 3.32 \\
\hline & & & Boring caterpillars & 37 & 84.99 & 8.19 \\
\hline & & & Other & 1 & 2.30 & 0.22 \\
\hline & & & Total & 53 & 121.74 & 11.73 \\
\hline \multirow{10}{*}{ Aug $12-$ Sept 03} & 375 & 861.38 & Missing & 63 & 144.73 & 13.94 \\
\hline & & & Empty burrs & 83 & 190.65 & 18.36 \\
\hline & & & Dichocrocis punctiferalis & & 64.00 & 6.16 \\
\hline & & & Ch. ruficirra & & 5.00 & 0.48 \\
\hline & & & Cydia splendana & & 1.00 & 0.10 \\
\hline & & & Curculio spp. & & 0.00 & 0.00 \\
\hline & & & $N$. castanes & & 0.00 & 0.00 \\
\hline & & & Diseases & & 41.00 & 3.95 \\
\hline & & & Other & & 1.00 & 0.10 \\
\hline & & & Total & & 447.38 & 43.09 \\
\hline Yield & & 414 & & & & 39.88 \\
\hline
\end{tabular}

* Based on a sample of 19 trees and 2.297 chestnuts per burr.

\begin{tabular}{|c|c|c|c|c|c|c|}
\hline Sample Interval & $\begin{array}{c}\text { Number alive } \\
\text { (burrs) }\end{array}$ & $\begin{array}{l}\text { Number alive } \\
\text { (chestnuts) }\end{array}$ & Factor & $\begin{array}{l}\text { Number affected } \\
\text { (burrs) }\end{array}$ & $\begin{array}{l}\text { Number affected } \\
\text { (chestnuts) }\end{array}$ & Percent Affected \\
\hline \multirow[t]{4}{*}{ Up to July 06} & 495 & 1190.97 & Mecorhis cumulatus & 14 & 33.68 & 2.83 \\
\hline & & & Boring caterpillars & 12 & 28.87 & 2.42 \\
\hline & & & Other & 6 & 14.44 & 1.21 \\
\hline & & & Total & 32 & 76.99 & 6.46 \\
\hline \multirow[t]{4}{*}{06 July- Aug 08} & 463 & 1113.98 & Missing & 44 & 105.86 & 8.89 \\
\hline & & & Boring caterpillars & 76 & 182.86 & 15.35 \\
\hline & & & Other & 0 & 0.00 & 0.00 \\
\hline & & & Total & 120 & 288.72 & 24.24 \\
\hline \multirow[t]{10}{*}{ Aug 08-05 Sep } & & 825.26 & Missing & 147 & 353.68 & 29.70 \\
\hline & & & Empty burrs & 9 & 21.65 & 1.82 \\
\hline & & & Dichocrocis punctiferalis & & 6.00 & 0.50 \\
\hline & & & Ch. ruficirra & & 8.00 & 0.67 \\
\hline & & & Cydia splendana & & 1.00 & 0.08 \\
\hline & & & Curculio spp. & & 30.00 & 2.52 \\
\hline & & & N. castanes & & 50.00 & 4.20 \\
\hline & & & Diseases & & 12.00 & 1.01 \\
\hline & & & Other & & 10.00 & 0.84 \\
\hline & & & Total & & 492.34 & 41.34 \\
\hline Yield & & 333 & & & & 27.95 \\
\hline
\end{tabular}

* Based on a sample of 19 trees and 2.406 chestnuts per burr.

July that reached maturity and were harvested varied from a high of $45.19 \%$ in the relatively intensively managed Tianpu Forest Extension Station orchard to a low of $27.95 \%$ at Xinji.

\section{Missing Burrs}

Missing burrs were found to be the highest cause of chestnut loss in three of the four orchards (Tables 1-4, Fig. 2). These losses may have been the result of burr abortion, especially on trees with exceptionally heavy crops, or insect attack that may have resulted in an aborted burr that could not be accounted for. Analysis of 50 aborted burrs collected in the two sample orchards at Tianpu in late August indicated that about $20 \%$ was due to maturing of the chestnuts and $80 \%$ was due to infestation by the lepidopterous borer, Cydia (=Laspyresia) splendana Hübner (Lepidoptera: Olethreutidae). A proportion of the cause of missing burrs could possibly be accounted for by reducing the interval between sample periods.

\section{Insects}

Insect damage was the second most frequently encountered loss factor in three of the orchards and the most common loss factor in the Wuchenhe orchard. Levels of insect caused losses ranged from 12.75 to $28.58 \%$ (Fig. 2). The highest level of insect damage occurred in the Xinji Orchard, the oldest of the four orchards sampled with the tallest trees.

All of the insect damage was attributed to two groups of insects: weevils (Coleoptera: Curculionidae) and nut-boring caterpillars (Lepidoptera).

Curculionidae, identified as damaging to chestnuts in XinXian County, included Mecorhis cumulatus (Voss), Curculio davidi Fairmaire, and Niphades castanes Chao. $M$. cumulatus is active early in the growing season (Tables 1-4) and damages chestnuts by adults feeding on branches containing burrs. This causes branches to break, killing the newly formed chestnut burrs (Fig. 3). Adults of $C$. davidi and N. castanes feed 


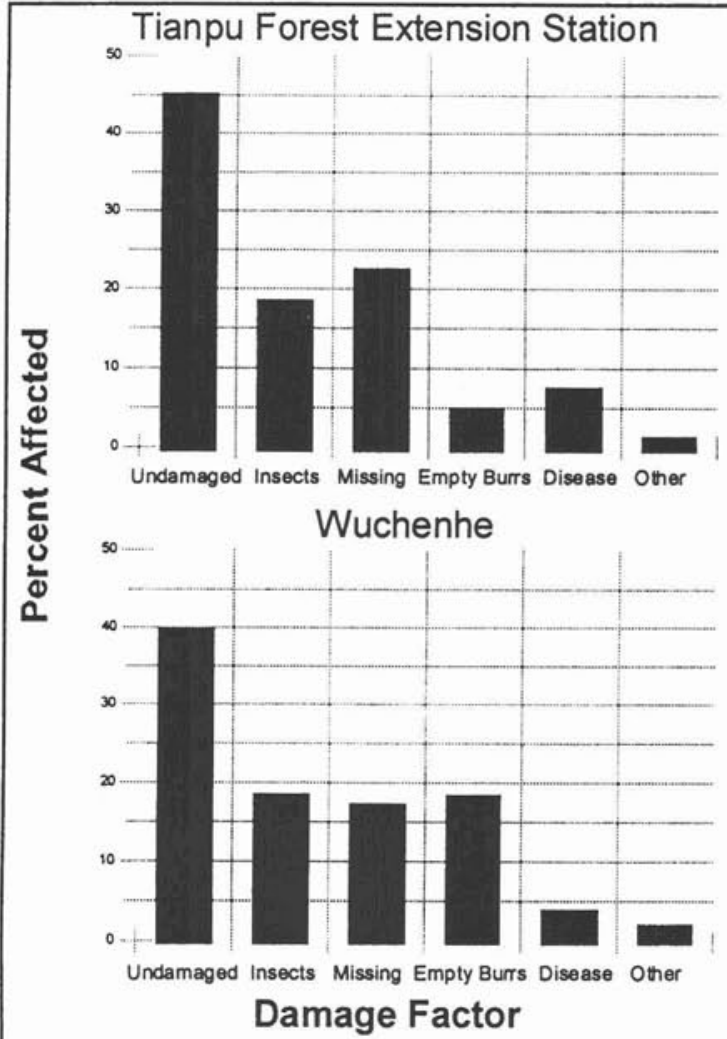

Damage Factor

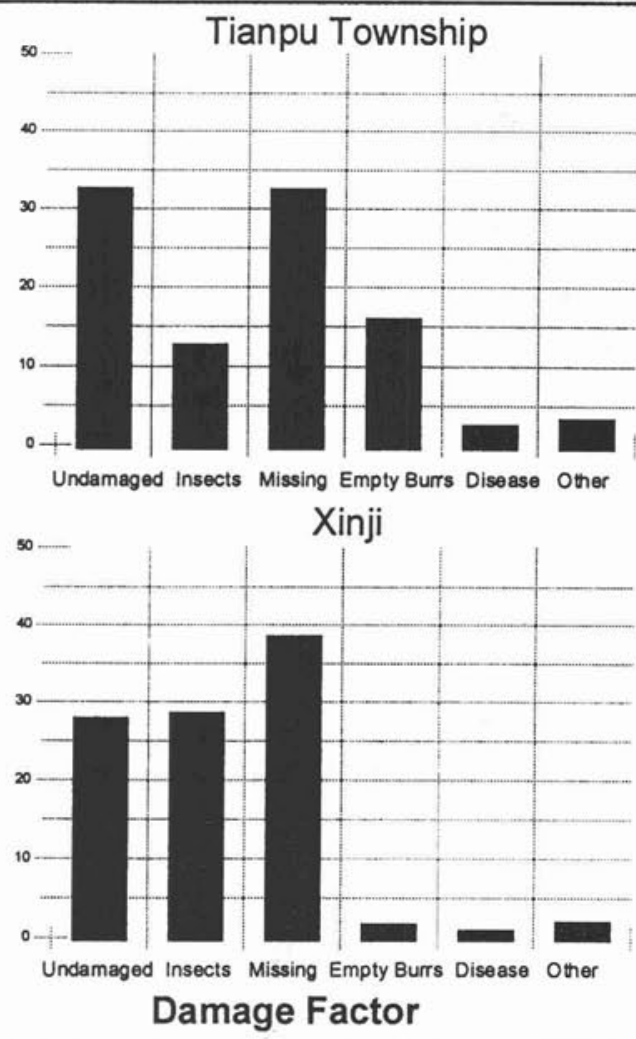

Fig. 2. Summary of chestnut losses by damage factor in four chestnut orchards, XinXian County, Henan Province, China -2000 .

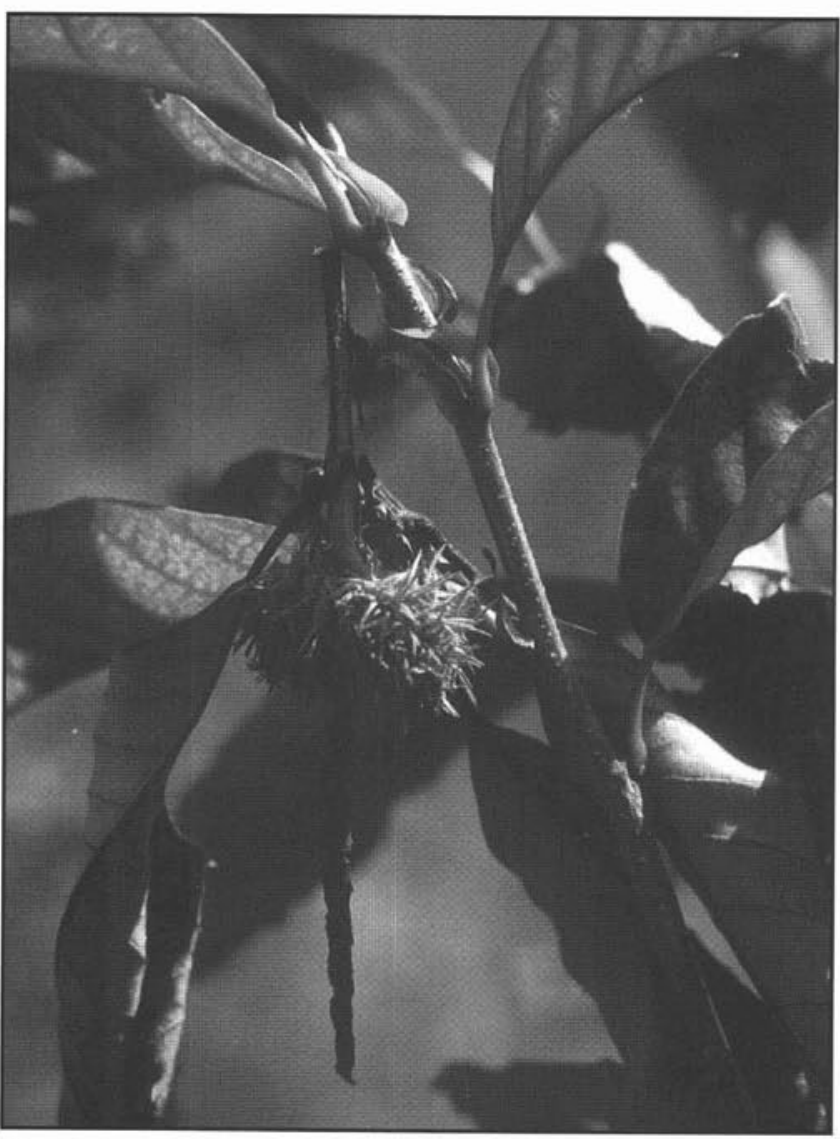

Fig. 3. Branch breakage and associated chestnut burr mortality caused by feeding of adult Mechoris cumulatus (Coleoptera: Curculionidae). by piercing the chestnuts with their snouts. Female adults later lay eggs in the feeding holes and the larvae feed on the nutmeat. Various species of Curculio are pests of nuts and acorns of Carya sp., Castanea sp., Corylus sp., Lithocarpus sp. and Quercus sp. throughout the Northern Hemisphere (Furniss and Carolyn 1977, Drooz 1985, Bessin 1997, AliNiaze 1998, Fukumoto and Kajimura 1999). Damage by C. davidi was found in chestnuts in two of the orchards sampled: Tianpu Forest Extension Station where $0.18 \%$ of the crop was damaged (Table 1) and Xinji, where $2.52 \%$ of the crop was damaged (Table 4 ). Damage attributed to $N$. castanes was found in only one orchard (Xinji) where it was responsible for $4.20 \%$ of the crop loss (Table 4).

Three species of nut-boring caterpillars were encountered during the monitoring: the yellow peach borer, Dichocrocis punctiferalis Guenee (Lepidoptera: Pyralidae), Characoma ruficirra Hampson (Lepidoptera: Noctuidae) and Cydia (= Laspyresia) splendana Hübner (Lepidoptera: Olethreutidae). Infestation by $D$. punctiferalis and $C h$. ruficirra is visible on the outer surface of the burr and consists of a mass of webbing and frass, sometimes accompanied by a brown discoloration of the burr, and was quantified during the July and August field sampling (Fig. 4). Infestation by $C$. splendana is not visible externally and levels of damage could only be determined after the burrs were removed from the trees, opened and examined during harvest. Overall losses caused by boring caterpillars was $16.92 \%, 12.76 \%, 18.25 \%$ and $19.02 \%$ for the Tianpu Forest Extension Station, Tianpu Township, Wuchenhe and Xinji orchards, respectively and comprised the largest class of insect damage. Most of the borer damage occurred in August.

Another insect observed during the monitoring was the chestnut gall wasp, Dryocosmus kuriphilus, which attacks vegetative buds and disrupts shoot growth through formation of a gall, 


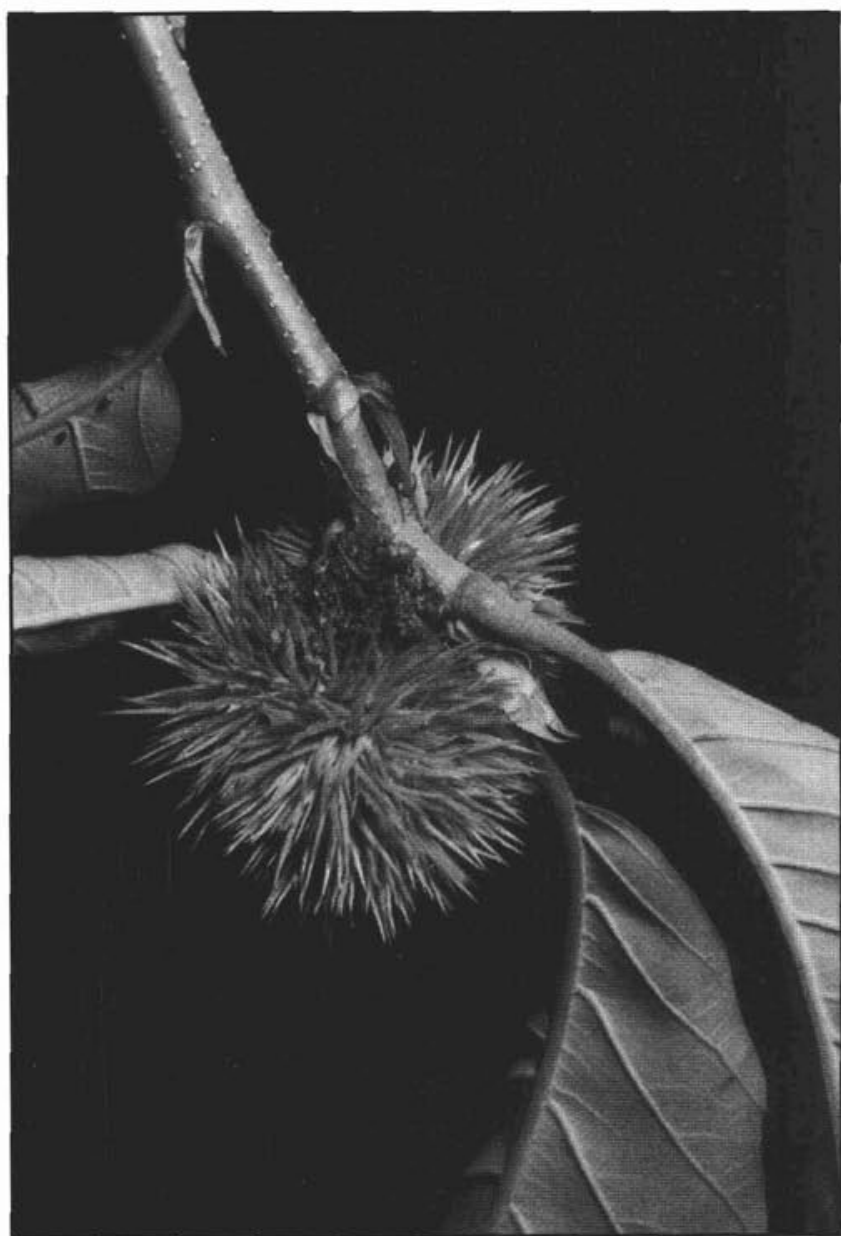

Fig. 4. Webbing and frass on chestnut burr associated with infestation by Dichocrocis punctiferalis or Characoma ruficirra.

suppresses shoot elongation and reduces fruiting. This insect is native to China and has been accidentally introduced into Japan, Korea and the southeastern USA, where it has become a serious pest (Payne 1978). In XinXian County, it apparently prefers to attack vegetative buds in the interior crown of chestnut trees whereas chestnut burrs are produced in the outer crown. Although common, chestnut gall wasp appeared to have little or no effect on chestnut production.

\section{Empty Burrs}

The presence of empty burrs was a significant factor affecting yields in two of the orchards: Tianpu Township $(16.07 \%$, Table 2) and Wuchenhe (18.36\%, Table 3). These orchards did not receive an early spring application of boron fertilizer, a treatment believed to increase nut set. (Anon. n.d.).

\section{Other Damage Factors}

Other factors responsible for chestnut crop damage included disease, mainly caused by the fungi Dothiorella greyaria and Colletotrichum gloeosporiodes, and other or unknown damage, primarily dead burrs for which no specific cause of death could be attributed.

The chestnuts classified as diseased were partially or wholly black and covered with an unidentified grey-white fungus, which may have been a secondary infection. The damage extent of disease was distinctly heavier in the orchard managed by Tianpu Forest Extension Station.

\section{Discussion}

Life tables, if based on data for the complete cycle of a population or crop, are capable of showing the accumulative effects of all factors throughout the life span of the organism or crop monitored (Graham 1963). Moreover, life tables can show when a population is subject to a specific damage or mortality factor.

The life table approach has been previously used in China for monitoring losses in Abies and Pinus cone crops (Yuan Ronglan et al. 1996, Wen Junbao et al. 1997, Chen Meixiang 1999) and, on at least one occasion, chestnuts (Xi Ke et al. 1996). The life table study on chestnut crops by Xi Ke et al. (1996) was confined to examination of burrs, however, and did not estimate nut yields.

The life tables presented in this paper are partial life tables because the first set of observations was not initiated until early July 2000. Chestnut burrs were well developed at this time and subject to about six weeks of exposure to damage, much of which was not captured by the early July observations. Therefore, the proportion of chestnuts surviving to harvest may be somewhat lower than shown in these life tables. Moreover, these life tables do not take into consideration annual variations in burr production, pest numbers and other factors affecting chestnut yields. The degree of variation must be determined through continuous monitoring of the chestnut crop.

\section{Conclusions}

The following conclusions may be drawn from this work:

1. Overall chestnut losses from all factors was high in all orchards monitored, with less than $50 \%$ of the burrs present in early July reaching maturity and harvest.

2. Missing burrs were the highest cause of chestnut loss in three of the four orchards sampled. Some of this may be the result of chestnut burrs aborting because of insect attack. In other cases, it may be the result of spontaneous abortion or early maturation of chestnuts. A proportion of this loss could possibly be accounted for by reducing the interval between sample periods to two to three weeks.

3. Losses that could be directly attributed to insects ranged between 12.75 and $28.58 \%$. The highest level of insect damage occurred in the Xinji Orchard. This was the oldest of the four orchards sampled, contained the tallest trees and would be the most difficult to treat with insecticides using the ground application equipment currently available. Most of the insect damage was attributed to a complex of caterpillars that bore into chestnuts.

4. Occurrence of "empty burrs" was roughly equal to insect damage levels in two of the orchards (Wuchenhe and Tianpu Township). These orchards did not receive a supplemental boron fertilizer treatment at the time of flowering.

5. Based on monitoring data obtained during the 2000 growing season, it is apparent that the most significant opportunities to increase chestnut production are application of boron to increase nut set and development of an IPM system focused on lepidopterous borers. The latter should emphasize approaches other than use of chemical pesticides. Monitoring of the pest complex and resultant losses should be continued over several more growing seasons and investigations should be made on pest occurrence during the post harvest period. 


\section{Acknowledgements}

Technical and editorial review provided by Gillian Allard, Forest Protection Officer and Christel Palmberg, Director, Forest Resources Management Service, Forestry Department, Food and Agriculture Organization of the United Nations, Rome, Italy is gratefully acknowledged.

\section{References}

AliNiaze, M.T. 1998. Ecology and management of hazelnut pests. Annual Review of Entomology. 43: 395-419.

Anonymous, n.d. Potentials for a North American chestnut industry. On line-http://www.traverse.com/earthkeepers/potential.html. Bessin, R. 1997. Nut weevils. University of Kentucky, College of Agriculture. 3 p.

Chen Meixiang. 1999. A study on life table of Chinese fir cones. Journal of Fujian College of Forestry 19(1): 91-93. (In Chinese).

Drooz, A.T. 1985. Insect enemies of eastern forests. USDA Forest Service, Miscellaneous Publication 1426. 608 p.
Fukumoto, H. and H. Kajimura. 1999. Seed insect fauna of predispersal acorns and acorn seasonal fall patterns of Quercus variabilis and Q. serrata in Japan. Entomological Science 2: 197-203.

Furniss R.L. and V.M. Carolin. 1977. Western forest insects. USDA Forest Service, Miscellaneous Publication 1339. 654 p.

Graham, K. 1963. Concepts of forest entomology. Rheinhold Publishing Company, New York, USA. 388 p.

Payne, J.A. 1978. Oriental chestnut wasp: A new pest in North America. In Proceedings of the American chestnut symposium, West Virginia University, Morgantown, WV, USA. pp. 86-88.

Wen Junbao, Li Zhenyu and Shen Xihuan. 1997. Analysis of cone life table of Pinus tabulaeformis Carr. and the yield and quality of cones damaged by insects. Journal of Beijing Forestry University 19(3): 33-38 (In Chinese).

Xi Ke, Xu Fuyuan and Dai Yusheng. 1996. A study on life table of chestnut fruits. Journal of Jiangsu Forestry Science and Technology 23(4): 6-10. (In Chinese).

Yuan Ronglan, Tang Cai, Yu Qilong and Xi Xinji. 1996. The life table of Taiwan pine cones. Journal of Zhejiang Forestry College 13(4): 427-434. (In Chinese). 